\title{
A Thermal Analysis-Based Approach to Identify Different Waste Macroplastics in Beach Litter: The Case Study of Aquatina di Frigole NATURA 2000 Site (IT9150003, Italy)
}

\author{
Mariaenrica Frigione ${ }^{1}$ (D), Gabriele Marini ${ }^{2,3}$ and Maurizio Pinna ${ }^{2,3, *(D)}$ \\ 1 Department of Engineering for Innovation, University of Salento, 73100 Lecce, Italy; \\ mariaenrica.frigione@unisalento.it \\ 2 Department of Biological and Environmental Sciences and Technologies, University of Salento, \\ 73100 Lecce, Italy; gabriele.marini@unisalento.it \\ 3 Research Centre for Fisheries and Aquaculture of Aquatina di Frigole, DiSTeBA, University of Salento, \\ 73100 Lecce, Italy \\ * Correspondence: maurizio.pinna@unisalento.it
}

check for updates

Citation: Frigione, M.; Marini, G.; Pinna, M. A Thermal Analysis-Based Approach to Identify Different Waste Macroplastics in Beach Litter: The Case Study of Aquatina di Frigole NATURA 2000 Site (IT9150003, Italy). Sustainability 2021, 13, 3186.

https://doi.org/10.3390/su13063186

Academic Editors: Marc A. Rosen and María Ángeles Martín-Lara

Received: 12 January 2021

Accepted: 10 March 2021

Published: 14 March 2021

Publisher's Note: MDPI stays neutral with regard to jurisdictional claims in published maps and institutional affiliations.

Copyright: (c) 2021 by the authors. Licensee MDPI, Basel, Switzerland. This article is an open access article distributed under the terms and conditions of the Creative Commons Attribution (CC BY) license (https:// creativecommons.org/licenses/by/ $4.0 /)$.

\begin{abstract}
The dispersion of commercial plastics in the marine environments is a major threat to biodiversity and ecosystem services of the last decades. The lower density of the plastics with respect to marine water density determines their floating, transferring, and accumulation in sandy beaches. Sandy beaches represent a natural sink ecosystem for marine plastics, where the latter are fragmented and photo-degraded in relation to the kind of polymer. Here, we propose an accurate and cost-effective method, the differential scanning calorimetry (DSC), to identify different polymers from plastic samples collected on the Aquatina di Frigole beach (Apulia Region, Southeast of Italy), included in the NATURA 2000 Site coded as IT9150003. Our results reveal the exclusive presence of thermoplastic polymers in the beach plastic samples, mostly belonging to the polyolefin family. They appear to be remnants of larger plastic fragments, which could impact biodiversity and ecosystem services such as beach recreation activities and tourism.
\end{abstract}

Keywords: sandy beaches; beach plastic litter; waste polymers; differential scanning calorimetry (DSC); Aquatina di Frigole NATURA 2000 Site

\section{Introduction}

Commercial commodity plastics consist of a large variety of polymers, mostly belonging to thermoplastic family, including polypropylene (PP), polyethylene (PE), polystyrene (PS), polyvinylchloride (PVC), polyethylene terephthalate (PET), and polyamide (PA). The majority of them are based on synthetic polymers, produced starting from fossil oil and designed to meet the different requirements of a wide variety of end products. Thanks to their versatility, durable nature, and high cost-effectiveness, plastics have played a crucial role in many strategic sectors in the last decades, such as packaging, the building and construction industry, transportation, electrical and electronic devices, agriculture, medical applications, and sport equipment [1,2]. In the last 50 years, in fact, world plastic production has increased from 1.7 tons up to reach 360 million tons per year [1].

Although polymers are typically considered as inert materials, nonetheless, the included chemical additives can be desorbed from them, entering the marine environments and causing severe harm to marine animals [3,4].

Nowadays, a large, often unavoidable use of plastics in modern society-in particular for packaging and single-use products-is exponentially increasing; as a consequence, the production of plastic waste is greatly increasing also, and spreading to such an extent that it is commonly recognized as a global concern that impairs ecosystems and threatens biodiversity [5-7]. Pollution due to plastics in marine environments is undoubtedly dependent on bad management of the waste plastics [1]. The most noticeable impacts 
in the marine environments are well-documented in the literature, including alterations in biodiversity and ecosystem health [8,9]; entanglement, smothering, and ingestion by marine species, such as large vertebrates as well as invertebrates [10-12]; and leaching of the mentioned plastic additives and chemicals, such as fillers, pigments, plasticizers, stabilizers, anti-oxidants, flame retardants [13].

Sandy beaches represent a natural sink environment for collecting the floating litter, which, after becoming stranded, generally becomes trapped in/under the sand or might be blown further inland [14]. Marine plastic litter stranded on beaches is also found along all the coasts of the Mediterranean Sea and has become a permanent concern, as well as a serious disturbance within the landscape and other aesthetic experiences of tourists and local visitors at beaches, as it curtails beach enjoyment [15].

Most studies dealing with beach plastic litter are based on measurements of quantities or fluxes (i.e., distribution, abundance, size and composition). They consider various litter categories, different samplings on transects and quadrates, other abiotic factors such as width and length of the beaches, transects in parallel or perpendicularly to the shoreline, and they regard both scientific surveys and/or clean-up campaigns [13-15]. Nevertheless, there are only a few studies addressing the polymeric composition of plastic litter samples in sandy beaches [16-18]. At present, data are only available on microplastic participles in beaches and coastal lagoons [19], in sediments [20] and on floating microplastics [21].

Analytical methods such as Fourier transform infrared (FT-IR) spectroscopy and micro-Raman spectroscopy have proven to be effective in identifying the polymer types of microplastics in environmental samples [22]. These techniques are based on the well-known infrared absorption bands that represent distinct chemical functionalities in the material analysed. However, the applicability of such common techniques has shown several drawbacks: (1) they require the extraction of the microplastics from environmental matrices including density separation, clean up steps and biomass removal; (2) large-sized samples must be analysed to confirm the composition of a plastic item composed of different polymers [23]; (3) these techniques are time consuming and laborious [24]; and (4) FT-IR and micro-Raman spectroscopy are not readily available everywhere [23]. In addition, polymers possessing the same chemical formula but different molecular structure, such as high density polyethylene (HDPE) and low density polyethylene (LDPE), are difficult to differentiate.

Therefore, in this research, we propose an alternative, simple and quick method for the identification of the polymers composing beach plastic litter based on a thermal analysis (TA) method: the differential scanning calorimetry (DSC). Thermal analyses, and in particular the DSC technique, are of extraordinary utility to characterize polymeric materials in a fast way; small sized sample can also be analysed, providing very reliable results. In addition, heterogeneous unpurified samples, even containing other materials, can be analysed, identifying the presence and kind of the polymer/polymers [17,23]. All of these aspects represent a novelty in this field of research.

This original study aims (1) to describe the beach plastic litter on the beach of Aquatina di Frigole, located along the Adriatic Sea coastline, in the Salento peninsula (Apulia Region, Italy), and included in the NATURA 2000 Site coded as IT9150003, and (2) to analyse the polymers composition of the plastic samples collected on the beach using the DSC technique. To reach these objectives, beach plastic litter was collected from two beach transects. Our findings provide novel details that can help future studies to reduce misleading results and increase identification accuracy with time-costs effectiveness.

\section{Materials and Methods}

\subsection{Study Area}

The sampling of marine plastic litter was carried out during April 2018 on the sandy beach of Aquatina di Frigole, located along the eastern Adriatic Sea coastline (Salento peninsula, Apulia Region, Italy). The beach (Lat. $40.4378^{\circ} \mathrm{N}$, Long. $18.2483^{\circ} \mathrm{E}$ ), about $13 \mathrm{~km}$ far from the City of Lecce in the locality of Frigole, is frequently visited by tourists during the 
summer months and is included in the NATURA 2000 Site named "Aquatina di Frigole" and coded as IT9150003.

The NATURA 2000 Site of Aquatina di Frigole covers a surface of 3,163 ha, encompasses marine and terrestrial habitats, and a lagoon separated from the beach by an extensive dune cordon. Some of the habitats included in the site that are in danger of disappearance have been given priority status under Annex I of the Directive 92/43/EEC, such as the $1120^{*}$ Posidonia beds (Posidonion oceanicae), 1150* coastal lagoons, and $2250^{*}$ coastal dunes with Juniperus spp. It also has a high variability of plant species including particular associations of considerable floristic and vegetation interest, such as the shrubs of the Mediterranean maquis, the salt steppe and different species of wild orchids. The lagoon constitutes a nursery environment for the juvenile stages of many fish species due to the wide availability of nutrients and food resources. Furthermore, the lagoon hosts different species of crustaceans, molluscs, and macrophytes [25-27]. Among these, the endemic Mediterranean bivalve Pinna nobilis is included in Annex IV of the Habitats Directive and is listed as an endangered species in the International Union for Conservation of Nature (IUCN) Red List [28-30]. In addition, the variety of environments and habitats in the entire protected area support numerous nesting and migratory birds of community importance such as pairs of ardeidae Ardea cinerea, Ardea alba, Egretta garzetta and flocks of Phalacrocorax carbo. The rapacious Circus aeruginosus, which nests in the spring between the vegetation that surrounds the lagoon, can also be sighted, whereas, among the anatids, Anas platyrhynchos, Anas acuta, Anas querquedula and Anas crecca can be found.

\subsection{Sample Collection and Handling}

In April 2018, two transects (T1, T2) spanning from the strandline to the base of dunes were surveyed on the Aquatina di Frigole sandy beach. Along each transect, three sampling sites ( $\mathrm{A}=$ intertidal zone, $\mathrm{B}=$ medium beach, $\mathrm{C}=$ base of dune) were fixed. The two transects were chosen in a limited area of the beach characterized by the accumulation of marine litter and plastics with the aim to collect a high number of plastic categories and polymers. Three replicates of $30 \mathrm{~cm} \times 30 \mathrm{~cm}$ were collected randomly in each sampling site. Within each $0.09 \mathrm{~m}^{2}$ replicate, the plastic litter was collected from the surface up to $10 \mathrm{~cm}$ deep using a box-corer and later it was sieved with a two-millimeter-mesh-size sieve. The retained sample on the sieve was cleaned with tap water in the nearby Research Centre of Fisheries and Aquaculture of Aquatina di Frigole (branch laboratory of the University of Salento) and then air-dried. Some collected samples are shown in Figure 1 with the aim to give a visual description of the plastic items sampled.

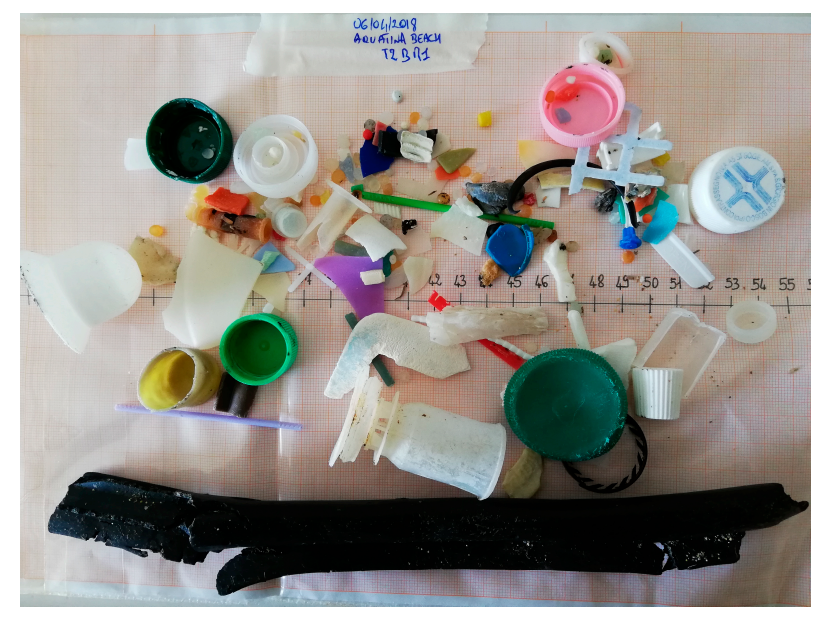

Figure 1. Example of the plastic items collected from Aquatina di Frigole beach. The photo contains the plastic items of a single plot/replicate (sandy beach plot of $30 \mathrm{~cm} \times 30 \mathrm{~cm} \times 10 \mathrm{~cm}$ ); the label about the sampling time, sampling station and replicate is also reported. 
Afterwards, each plastic piece was weighed using a microbalance Sartorius MC21S ( $\pm 0.001 \mathrm{~g})$ and then the plastic pieces were grouped into 11 main categories according to the different material types: pellets, straws and lolly sticks, bottles, bottle caps, rubber pieces, polystyrene, string and cords, plastic fragments (sizes $<0.5 \mathrm{~cm}$, comprised between $0.5 \mathrm{~cm}$ and $10 \mathrm{~cm},>10 \mathrm{~cm}$ ) and objects composed of different materials. The collected items, grouped by category, were then counted and weighed with a microbalance $\pm 0.001 \mathrm{~g}$ (Sartorius MC21S) for transect, sampling station, and plot/replicate. Finally, we selected a subset of plastic items for each category as different as possible, taking into account color, shape, and degradation state; each selected item was then analysed using a Mettler Toledo 822 differential scanning calorimeter..

\subsection{Differential Scanning Calorimetry to Identify Different Polymers}

The identification of the polymer/polymers composing each of the picked up plastic item was carried out with the aid of a differential scanning calorimeter (DSC). To the best of our knowledge, this is one of the first studies present in the literature that uses DSC to identify and analyse the polymers collected from a coastal environment $[17,31]$.

Differential scanning calorimetry belongs to the thermal analyses (TA), a set of analytical techniques able to measure the properties or property changes of materials, even materials other than polymers, as a function of temperature or time. TA techniques allow the identification and analysis of the physical properties of a substance as a function of the temperature (or time) when this substance is subjected to a controlled temperature program [32]. In the field of polymer science, thermal analyses, and in particular the heat flow DSC, are of extraordinary utility to characterize polymeric materials in a simple and fast way.

A DSC instrument, in particular a DSC at heat flow, measures the difference in thermal flux between a matter sample and a reference inert sample, typically the gas present in the cell of measurement, both placed in an oven. The instrument is equipped with thermocouples, placed under the samples, able to measure the temperature difference between the matter sample and the inert reference. Each thermal event involving a change of specific heat in the sample, or the development/absorption of heat in the same, generates a difference in temperature between the sample and the reference; the instrument converts this difference to a heat flow difference, quantifying this difference. From the analysis of the obtained curve, known as "thermogram", it is possible to identify the different thermal events occurring in a material, such as, in the case of polymers: glass transition, melting, crystallization, and degradation.

Since each polymer is characterized by a defined range of temperatures in which it displays the glass transition, melting, crystallization, or degradation processes, an accurate analysis of the thermograms found for the unknown polymers, and a subsequent careful interpretation of results, allows for the identification of the different polymers, as those found on a beach.

The thermal characteristics of a polymer, apart from its chemical composition, structure, and molecular weight, depend also on other parameters, such as the employed processing methods and conditions [33,34]. To a certain extent, they are also affected by the additive used in the compounding stage and by the degradation level. The success of this analysis for the identification of different polymers, therefore, requires a deep knowledge of the DSC technique and of the thermal behavior of different commercial polymers.

A Mettler Toledo DSC 822 instrument was employed in the present study. The procedure employed for the DSC tests was the following: for each plastic item, a small sample (average weight 6 to $15 \mathrm{mg}$ ) was cut, weighed, and inserted in a standard aluminum crucible (supplied by the Mettler Company). The crucible was covered with an aluminum lid; on the lid, a small hole was made, in order to allow the drainage of the gas released as a consequence of the heating of the material under analysis. The crucible containing the material was then introduced in the DSC oven. The experiments were performed in dynamic mode, employing a constant heating rate of $10^{\circ} \mathrm{C} / \mathrm{min}$ from $15^{\circ} \mathrm{C}$ to $250{ }^{\circ} \mathrm{C}$. The selected 
range of temperatures was chosen after a certain number of experiments in which it was assessed that no thermal phenomenon, apart from thermal degradation, was observed at temperatures greater than $250{ }^{\circ} \mathrm{C}$. The experiments were carried out under nitrogen atmosphere (flow rate: $80 \mathrm{~mL} / \mathrm{min}$ ) in order to avoid the occurrence of thermo-oxidative processes, able to prevent the melting of the polymer. For the purpose of repeatability, the calorimetric experiments were repeated at least twice and the results were averaged.

From the DSC tests, employing the acquisition data system connected with a dedicated software-STARe-it was possible to determine the glass transition temperature (Tg) and /or melting peak temperature (Tp) and enthalpy $(\Delta H)$ of the polymers composing the plastic items under analysis and, consequently, to identify the kind of polymers by comparing these characteristics with those present in the literature for different polymers.

\section{Results}

A total of 1168 plastic items for a total weight of $535.6 \mathrm{~g}$ were gathered from 18 sampling plots/replicates $(30 \mathrm{~cm} \times 30 \mathrm{~cm} \times 10 \mathrm{~cm})$ on the Aquatina di Frigole beach along two transects in which three sampling stations were identified with respect to the distance from the sea, such as: $\mathrm{A}=$ intertidal zone; $\mathrm{B}=$ medium beach; $\mathrm{C}=$ base of the dune. In five sampling plots/replicates, no plastic items were collected (Table 1).

Table 1. Numbers of the plastic litter items in the collected samples and grouped into eleven categories. $(\mathrm{T} 1, \mathrm{~T} 2=$ transect; A, B, C = sampling station; R1, R2, R3 = plot/replicate). No items were collected in the following plots/replicates: T1AR1, T1AR2, T2AR1, T2AR2, T2AR3.

\begin{tabular}{|c|c|c|c|c|c|c|c|c|c|c|c|c|c|}
\hline \multirow[b]{2}{*}{ Categories } & \multicolumn{13}{|c|}{ Beach Plastic Plots/Replicates } \\
\hline & T1AR3 & T1BR1 & T1BR2 & T1BR3 & T1CR1 & T1CR2 & T1CR3 & T2BR1 & T2BR2 & T2BR3 & T2CR1 & T2CR2 & T2CR3 \\
\hline Bottle caps & 0 & 1 & 1 & 1 & 2 & 3 & 0 & 8 & 2 & 4 & 2 & 3 & 3 \\
\hline Pellets & 1 & 3 & 42 & 7 & 26 & 92 & 65 & 91 & 34 & 50 & 16 & 89 & 47 \\
\hline Straws and lolly sticks & 0 & 0 & 3 & 0 & 1 & 4 & 2 & 3 & 4 & 0 & 3 & 4 & 4 \\
\hline Polystyrene & 0 & 0 & 4 & 0 & 0 & 4 & 8 & 6 & 1 & 0 & 7 & 15 & 24 \\
\hline Bottles & 0 & 0 & 0 & 0 & 0 & 0 & 0 & 0 & 0 & 0 & 1 & 0 & 0 \\
\hline Rubber & 0 & 0 & 1 & 0 & 0 & 0 & 0 & 3 & 0 & 0 & 0 & 0 & 0 \\
\hline String and cords & 0 & 0 & 0 & 0 & 0 & 0 & 0 & 0 & 0 & 0 & 1 & 0 & 2 \\
\hline Large fragments & 0 & 0 & 0 & 0 & 0 & 0 & 0 & 0 & 3 & 0 & 0 & 2 & 4 \\
\hline Medium-sized fragments & 0 & 3 & 22 & 3 & 16 & 17 & 18 & 80 & 38 & 44 & 18 & 60 & 35 \\
\hline Small fragments & 0 & 0 & 13 & 0 & 26 & 4 & 13 & 16 & 13 & 10 & 0 & 7 & 0 \\
\hline Objects of different materials & 0 & 0 & 0 & 0 & 0 & 0 & 0 & 0 & 0 & 0 & 0 & 4 & 1 \\
\hline
\end{tabular}

The number of plastic items was highest in the base of dune sampling stations (847 items, $141.17 \pm 30.87$ items/replicate), followed by medium beach (424 items, $70.67 \pm 19.86$ items/replicate), and intertidal zone sampling stations in which just one item was found in the T1AR3 plot/replicate; no items were found in any of the other plots of the intertidal zone sampling stations. It is interesting to note the high variability observed along the beach transect. Moving from medium beach to the base of dune, the number of items increased up to the $100 \%$. The greatest plastic weight per plot/replicate was observed at the base of dune (59.05 $\mathrm{g} \pm 22.41)$, followed at medium beach (30.22 $\mathrm{g} \pm 14.20)$, and at the intertidal zone $(0.005 \mathrm{~g}$, just one item) (Figure $2 \mathrm{~A}, \mathrm{~B})$. 

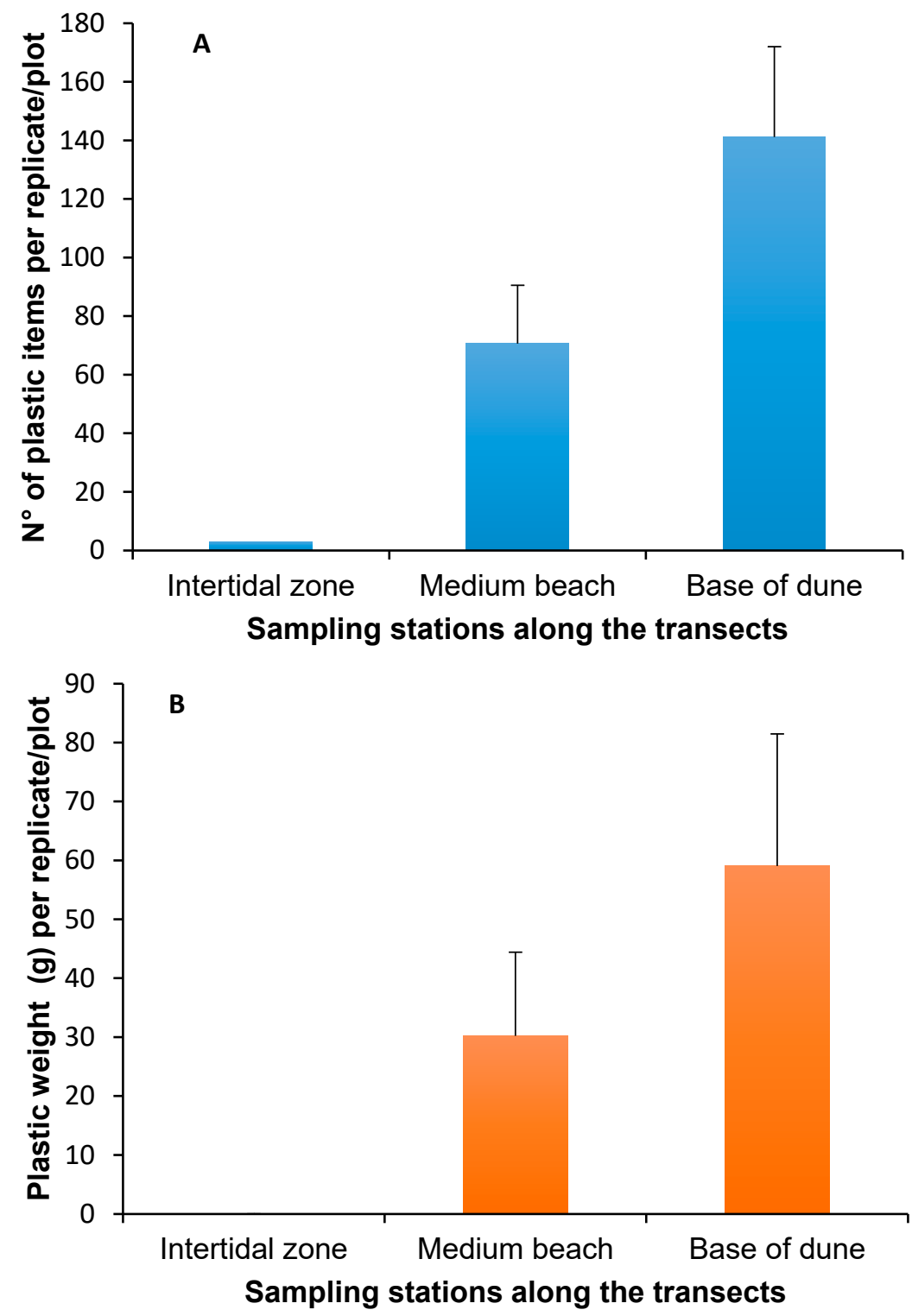

Figure 2. Number of plastic items per plot/replicate (A) and total plastic weight per plot/replicate (B) are reported for each of the sampling stations along the transects. Vertical bars represent the standard error.

In terms of the composition of plastic litter, pellets were the most abundant type $(48 \%)$, followed by fragments (31\%), polystyrene (6\%), and bottle caps $(3 \%)$. Conversely, string and cords made up only $2.4 \%$ of all plastic shape type. All plastic litter types were recorded both in medium beach and at the base of the dune, except for pellets, which were recorded in all sampling stations (Figures 3 and 4 ).

A subsample $(n=39)$ of the plastic items was selected to identify the different polymers employing a differential scanning calorimeter instrument. Most of the identified polymers belong to the thermoplastic polymeric family as polypropylene and polyethylene used in packaging, plastic bottles, plastic bags, and food containers. A few elastomers were also identified. In particular, the analysed beach litter plastics were identified as: 11 articles (bottle cups, straws, lolly sticks, fishing nets, strainers, small slabs, fragments) composed of isotactic polypropylene (iPP), eight objects (bottle cups, small slabs fragments) composed of high density polyethylene, five items (small cups, fragments) composed of lineal low density polyethylene (LLDPE), one object (a small slab) composed of polyethylene vinyl acetate (PEVA), one article (fragment of packaging foam) composed of polystyrene, six arti- 
cles (cups, small slabs, hollow objects) composed of a blend of low density polyethylene and polyethylene vinyl acetate, two items (fragments) composed of a blend of high density polyethylene and low density polyethylene, two articles (cups) composed of a blend of isotactic polypropylene and low density polyethylene, two objects (a small cup, a fragment) composed of a blend of isotactic polypropylene and linear low density polyethylene, one article (a fragment) composed of a blend of isotactic polypropylene and high-density polyethylene, one item (a small slab) composed of a blend of isotactic polypropylene and polyethylene vinyl acetate, and one object (a small slab) composed of a blend of high density polyethylene and polyethylene vinyl acetate. It was then found that isotactic polypropylene (iPP) was the dominant polymer used as the material for straws, lolly sticks, fishing nets, and some bottle caps. Its good chemical resistance and weld ability make it widely used in various applications and mostly it is an ideal material for fishing nets for its strength and moisture resistance. In the next paragraph, the main properties and characteristics of the polymers identified in the analysed waste are illustrated.

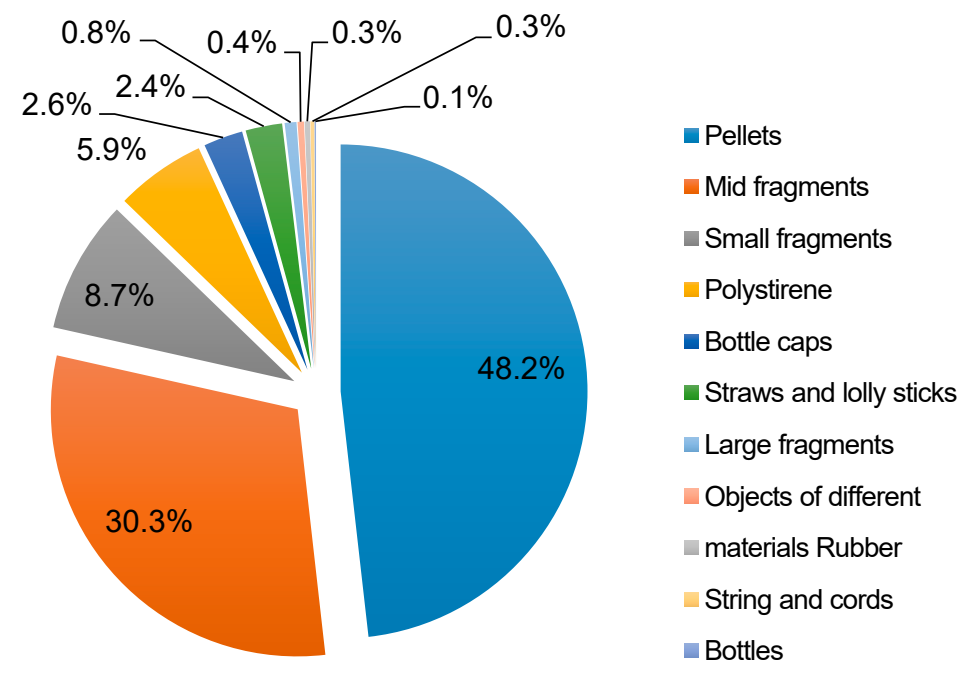

Figure 3. Percentage of abundance of all plastic litter categories/typologies detected in the Aquatina di Frigole beach.

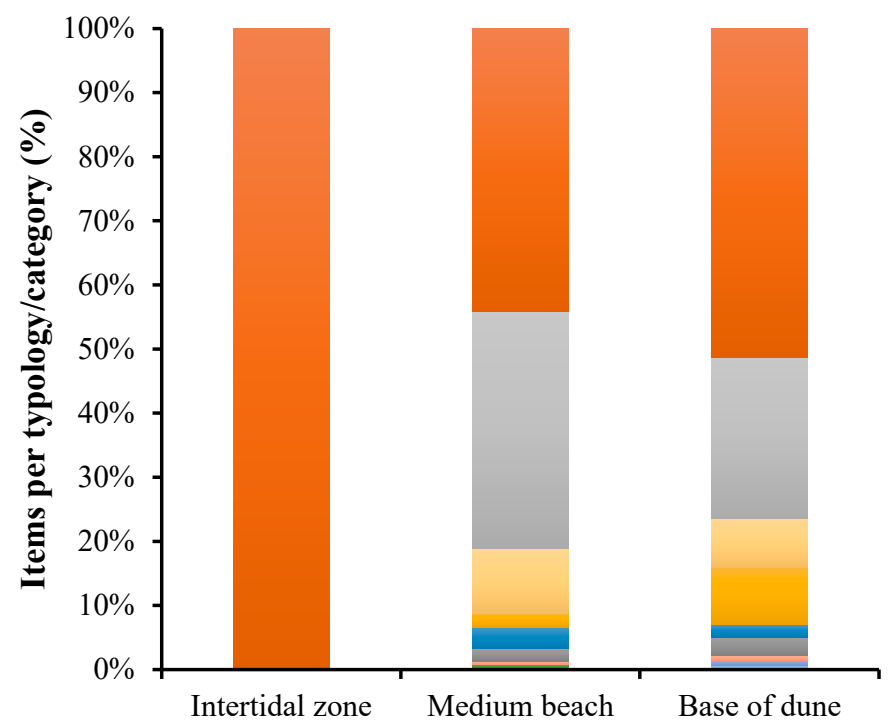

Pellets

Mid fragments

Small fragments

Polystirene

- Bottle caps

- Straws and lolly sticks

$\square$ Large fragments

- Objects of different materials

Rubber

$\square$ String and cords

- Bottles

Sampling stations along the transects

Figure 4. Composition of plastic items categories in the intertidal zone, medium beach and base of dune sampling stations. 
A commercial polymer material is usually supplied to transformation companies as powder or "pellets", i.e., small granules, and must be processed in order to obtain the final object. The latter were not presented in the present study since their width is in the range between microplastics and mesoplastics; therefore, they do not fulfill the objective of this study. They will be thoroughly analyzed and discussed in further manuscripts.

\section{Identification of Polymers through DSC}

In Figures 5 and 6, the chemical structure and DSC signals recorded for the analyzed plastic items are reported, respectively.<smiles>CC1CC1CC1CC1</smiles>

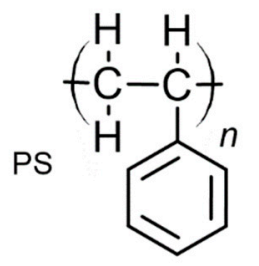<smiles>CC(C)C1CCC1C</smiles>

Figure 5. Chemical structure of the thermoplastic polymers identified in the study. From left to right: structures of the polyethylene (PE), polystyrene (PS) and polypropylene (PP).

The density and average peak temperature at melting, or glass transition temperature for PS, (according to [30]) for each polymer are reported in each enclosed table.

Isotactic polypropylene was first identified from the observation of its thermogram (reported in Figure 6A) in comparison with available data in the literature. It is a thermoplastic, rigid, highly crystalline polymer belonging to the polyolefin family, with a melting point around $165^{\circ} \mathrm{C}$; it is very stable and scarcely biodegradable [32]. iPP is widely used in many commercial applications, such as in textiles (fibers and fabrics), automotive components (car seats, bumps), medicine and health (medicine bottles, disposable syringes), furniture (carpets), as well as in packaging (caps, drinking straws, bottles) due to good barrier properties, along with good surface finish and low production costs. It is one of the polymers most frequently found in marine environments.

Polyethylene is a thermoplastic semi-crystalline polymer; it is one of the most employed polymers for different uses due to its cheapness and ease of production. PE is largely utilized in packaging (to produce plastic bags, milk bottles, thin films, etc.) and also to manufacture toys, pipes, and tanks [33]. It is intrinsically very resistant against microbial attack [34]. PE is the major polymer among those composing plastic litter found in marine ecosystems [18]. From the comparison of DSC traces with data reported in the current literature, it was possible to identify plastic items composed of three types of $\mathrm{PE}$, i.e., HDPE (Figure 6B), LDPE (Figure 6C), and LLDPE (Figure 6D). As suggested by their names, the different polyethylenes mainly differ in density (reported for each PE in the table displayed under each thermogram), and, as a consequence, in the development of the crystalline phase. With the DSC technique, therefore, it is possible to distinguish the type of polyethylene under investigation. HDPE is a linear polymer, characterized by a high density, largely used in the packaging industry. It is a highly crystalline polymer (up to 80 to $90 \%$ ) and it is characterized by a melting point of $127^{\circ} \mathrm{C}$ to $135^{\circ} \mathrm{C}$. Lowdensity polyethylene is a semi-crystalline, branched, thermoplastic polymer with a degree of crystallinity in the 50 to $60 \%$ range. Due to a mixture of favourable mechanical and physical properties and chemical resistance [33], it has been extensively used worldwide in industrial, agricultural, and domestic market, mainly for packing and wrapping frozen food, and to produce textile products and carrier bags. LLDPE is a linear polymer with a low density, possessing a degree of crystallinity typically between 35 to $60 \%$. As compared to LDPE, it displays a higher tensile strength and a higher impact resistance. It is employed in a variety of film applications also for its good chemical resistance and excellent water vapor and alcohol barrier properties. 

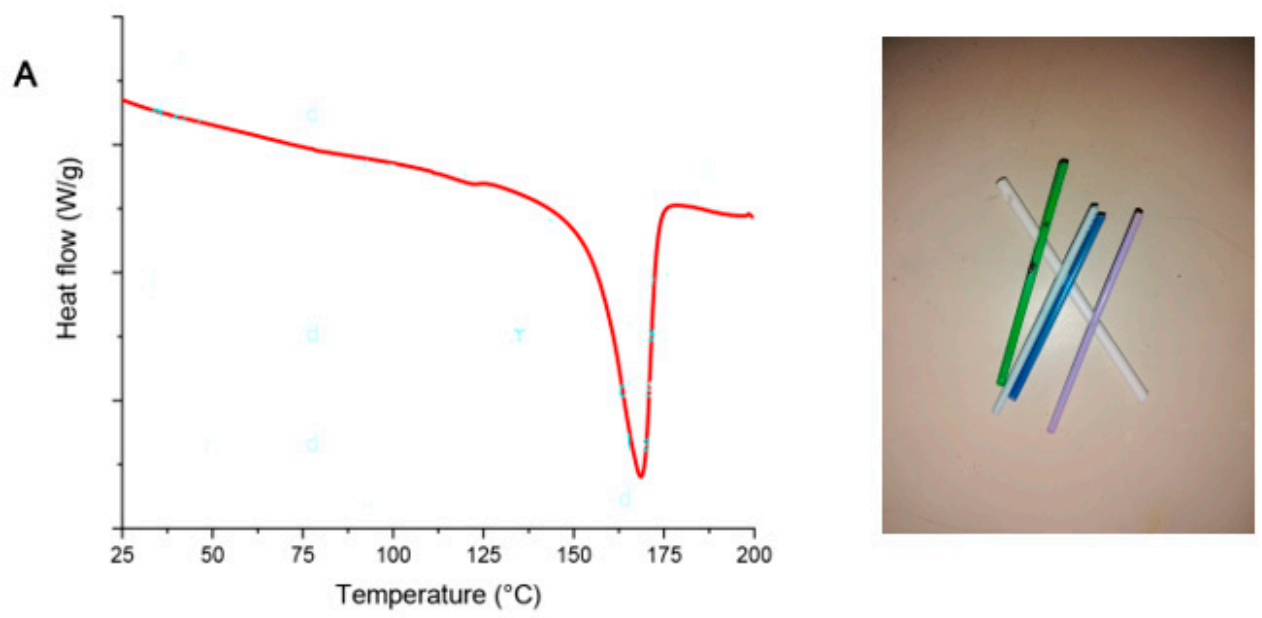

\begin{tabular}{|l|l|l|}
\hline Polymer & Density $\left(\mathbf{g}^{\star} \mathbf{c m}^{-\mathbf{3}}\right)$ & Peak temperature at melting $\left({ }^{\circ} \mathbf{C}\right)$ \\
\hline iPP & $0.90-0.91$ & $160-170$ \\
\hline
\end{tabular}
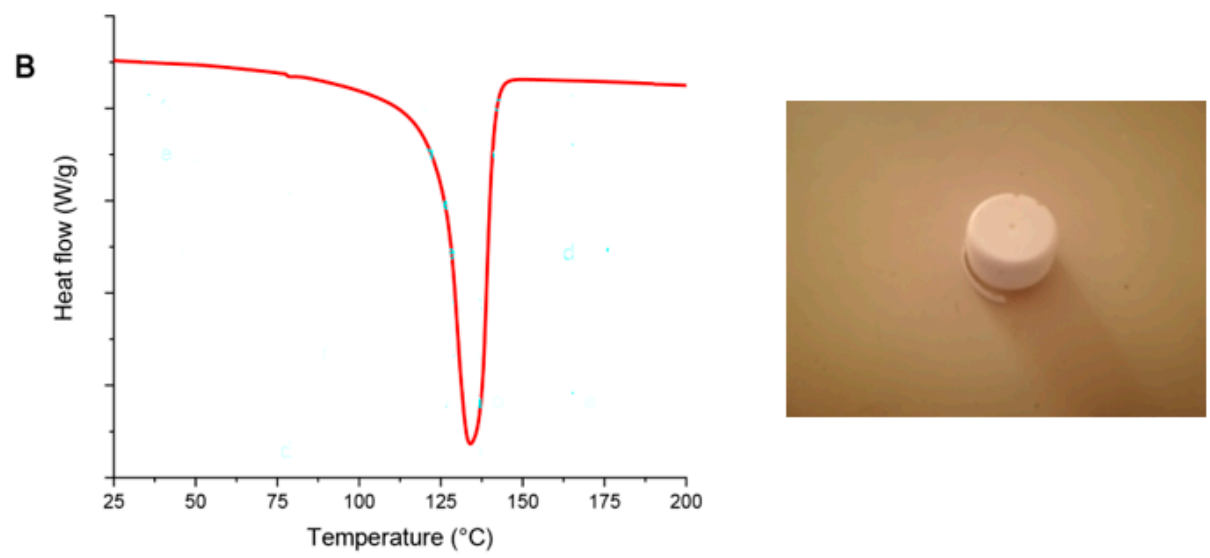

\begin{tabular}{|l|l|l|}
\hline Polymer & Density $\left(\mathrm{g}^{*} \mathbf{c m}^{-\mathbf{3}}\right)$ & Peak temperature at melting $\left({ }^{\circ} \mathbf{C}\right)$ \\
\hline HDPE & $0.95-0.97$ & $127-135$ \\
\hline
\end{tabular}

C

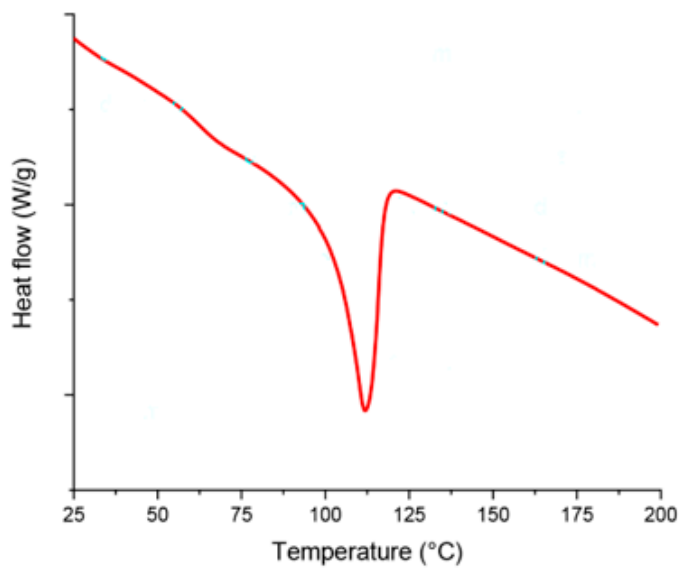

\begin{tabular}{|l|l|l|}
\hline Polymer & Density $\left(\mathrm{g}^{*} \mathrm{~cm}^{-3}\right)$ & Peak temperature at melting $\left({ }^{\circ} \mathbf{C}\right)$ \\
\hline LDPE & $0.91-0.93$ & $105-115$ \\
\hline
\end{tabular}

Figure 6. Cont. 

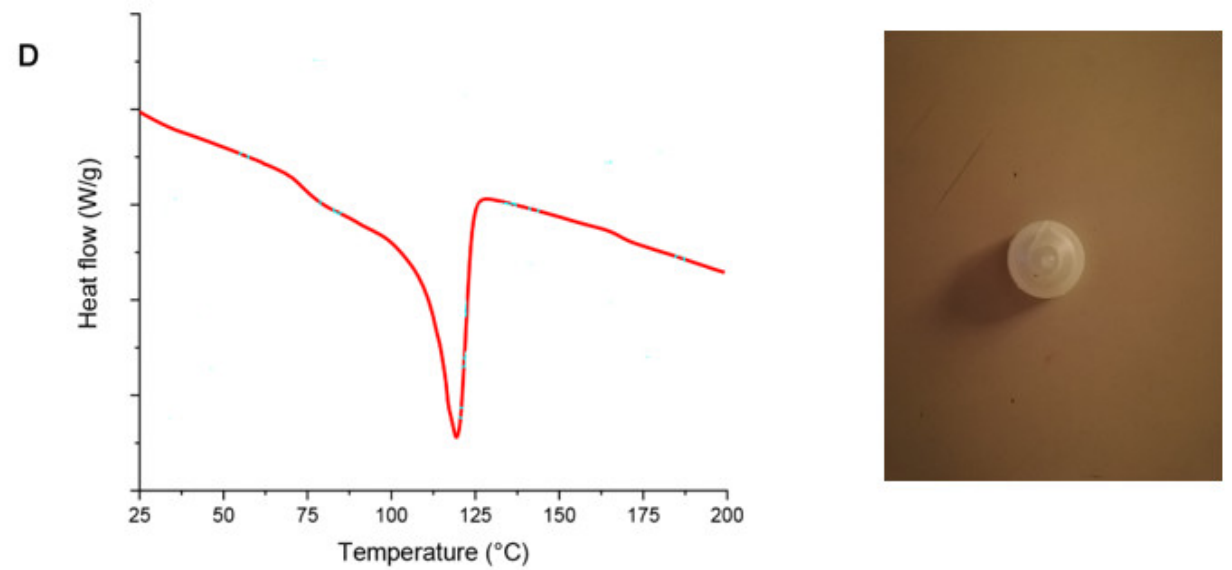

\begin{tabular}{|l|l|l|}
\hline Polymer & Density $\left(\mathbf{g}^{*} \mathbf{c m}^{-\mathbf{3}}\right)$ & Peak temperature at melting $\left({ }^{\circ} \mathbf{C}\right)$ \\
\hline LLDPE & $0.93-0.95$ & $118-125$ \\
\hline
\end{tabular}
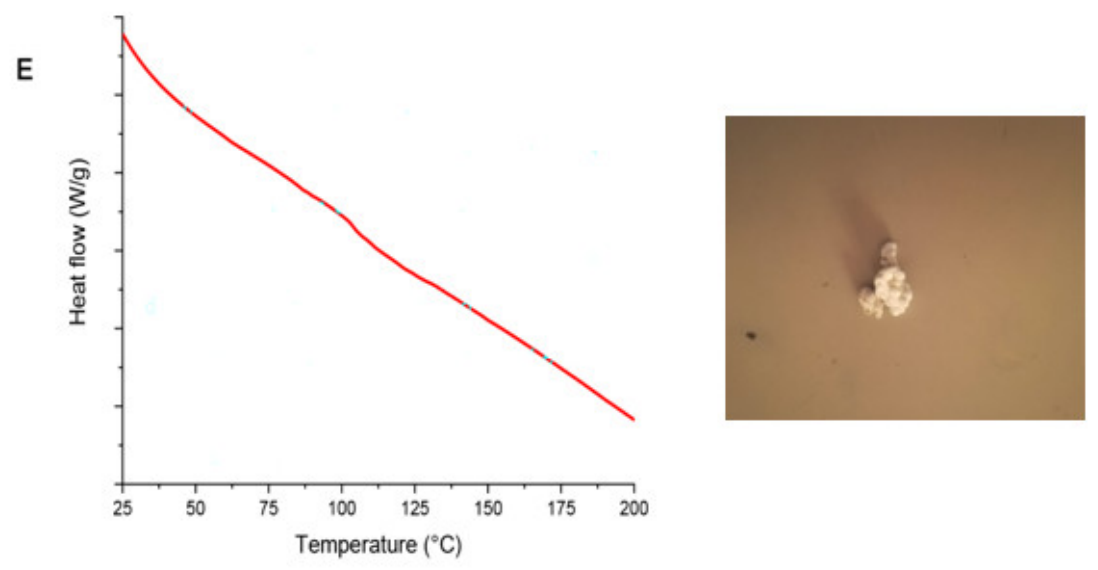

\begin{tabular}{|l|l|l|}
\hline Polymer & Density $\left(\mathrm{g}^{*} \mathbf{c m}^{-\mathbf{3}}\right)$ & Glass transition temperature $\left({ }^{\circ} \mathbf{C}\right)$ \\
\hline PS & $1.04-1.09$ & $95-100$ \\
\hline
\end{tabular}

Figure 6. DSC thermal plots for the plastic litter samples. Each plot shows the picture of the plastic item and the peak at melting point, except PS for which glass transition temperature is reported. From top to bottom: (A) isotactic polypropylene (iPP); (B) high density polyethylene (HDPE); (C) low density polyethylene (LDPE); (D) linear low density polyethylene (LLDPE); and (E) polystyrene (PS).

Another polymer was, finally, identified from its thermogram, shown in Figure 6E: it is polystyrene, an amorphous linear polymer [33]. Polystyrene can be identified by its glass transition temperature, $\mathrm{Tg}$, being for PS around $100^{\circ} \mathrm{C}$. PS is a hard and stiff polymer, displays excellent thermal and electrical insulation characteristics, is relatively inert to most chemicals, and absorbs low amounts of moisture. Polystyrene is, therefore, widely employed in the production of disposable cups, plates, and bowls, rigid trays for the food-service industry, packaging items, in laboratory ware and, due to its outstanding electric capabilities, in electronic devices. PS foam can also be commonly encountered as insulation and packaging material, to produce food containers (beverage cups, egg cartons, and disposable plates and trays). 


\section{Discussion}

We carried out the sampling on the Aquatina beach during April 2018. In the Mediterranean Ecoregion, the use for tourism and recreation of the beaches during April is very limited until the summer. Consequently, the main beach litter is represented by marine litter. Aquatina beach is exposed to main winds and marine current arriving from the north-northeast direction. We recognized Italian, Greek, Albanian, and Montenegro languages on the tagged macroplastics and supposed the origin of the items from the respective countries.

Polymer materials, sometimes also termed "plastics", can be defined as polymers modified with the addition of appropriate additives. Since polymers often cannot be used in their pure state, before their commercialization, they are subjected to proper processes, named "compounding", able to modify their properties by the addition of appropriate additives. Additives in polymers play an important role; a polymer needs to be modified whenever one or more of its properties are not adequate for the required applications. For instance, most polymers must be "stabilised", i.e., protected against external environmental agents (UV radiations, temperature, moisture, etc.). Some polymers can contain only small amounts of antioxidants to prevent them from oxidizing. Other polymers require large amounts of different additives, e.g., antioxidant, plasticizers, and fire retardants [35-39]. Polymeric materials may also necessitate the presence of large fractions of fillers, to reduce the whole costs and possibly to improve mechanical and/or functional properties. The introduction of additives in commercial plastics has given rise to severe environmental issues [3].

The actual risk of the spread of microplastics in marine environment is the adsorption and consequent deliverance of a wide variety of organic and inorganic chemicals and toxins $[2,6,9]$. In addition, increasing concentrations of chemical pollutants adsorbed through microplastics could result in their bioaccumulation in marine organisms via the ingestion [2] and bio-magnification of chemicals upward in the food chain, which may ultimately lead to contaminated seafood for humans as a result of plastic contamination in marine food-webs $[40,41]$. Plastic pollution and its spreading in the environment also has negative impacts on many economic sectors and ecosystem services, such as tourism, fisheries, and aquaculture, navigation and marine transport, recreation and cultural activities [42] as much as on human health, livelihoods, and wellbeing [43]. Pathways of the introduction of plastic litter in the environment are the result of anthropic and environmental sources. Plastic waste ends up in the marine environment when discharged into rivers, through rainwater, and wastewater, or when left directly on beaches. Once they reach the sea, marine litter items, depending on their densities, may float over long distances due to natural drivers [44] or sink to the seafloor, accumulating in areas of low hydrodynamism (bays and lagoons) or in the sediments [45]. In particular, the impact of marine plastic and microplastic litter stored in the Aquatina di Frigole beach can affect both vertebrate and invertebrate species with a high ecological value in terms of conservation and ecological monitoring [46]. Among these, recently, a juvenile specimen of Monachus monachus stopped on the beach [47], a population of Pinna nobilis has been observed [28,29], and the presence of polychaetes was also recorded [12,30].

Given that plastic waste is increasing in marine environments due to the increase of the production of single-use and multi-use plastic products, the identification of methods and procedures able to categorize plastic litter by polymer type and detect marine transport mechanisms and fates have become high research priorities. The determination of the kind of item found on beaches in relation to the plastic polymer type employed to produce it is the first step of the investigation focused on the transport and accumulation sites of the litter, which represents an important aspect for developing plastic pollution mitigation strategies. It must be kept in mind that many technological and management problems still exist when treating/disposing of the collected plastic waste.

A first advantage of the technique proposed in the present study, differential scanning calorimetry (DSC), resides in the possibility to quickly identify the type of polymer from a minimal quantity of material (i.e., a few milligrams). The different polymers are, in fact, 
characterized by distinctive peaks of melting, in terms of the maximum peak temperature, of the melting enthalpy and the shape of the melting process curve, and of the initial and final temperatures of the melting process. Furthermore, with DSC, it is possible to identify different types of polymers possessing the same chemical formula but different molecular weights and crystalline contents, such as high-density and low-density polyethylenes: this differentiation is hardly achieved with other commonly employed techniques, such as FTIR (Fourier-transform infrared spectroscopy) analysis. It must be underlined, finally, that the presence of substances eventually absorbed on plastic fragments, such as pollutants, contaminants and others, does not alter the DSC thermogram characteristic of each polymer due to their non-polymeric nature.

Within this context, our study revealed that most of the plastic waste collected on Aquatina di Frigole beach was composed of commercial polymers belonging to the polyolefin family-PP, HDPE, LDPE and LLDPE. Our findings are consistent with what has been found in other studies where beached plastics are dominated by polyolefins [48], with occasionally denser objects (e.g., PVC) or when entangled with natural benthic material such as kelp that are sometimes deposited in the intertidal zone [49]. Additionally, in Schwartz et al. (2019) [50], polyethylene and polypropylene were shown to be the most abundant polymers in the ocean beaches, followed by polystyrene. According to Schwarz et al. (2019) [50], polyethylene and polypropylene densities, in the range 0.9 to $1.0 \mathrm{~g} \mathrm{~cm}^{-3}$, are considerably lower than the densities of coastal seawater (about $1.02 \mathrm{~g}$ $\mathrm{cm}^{-3}$ ), ensuring that this material evades sinking and is subject to long-term transportation in suspension or beaching on the strandline, while denser material is deposited in the benthic environment and closer to its point of origin. Rochman et al. (2013) and Rochman et al. (2016) [6,9] have recognized that the density of marine litter is the main driver for their environmental fate.

Plastic pellets, accounting for $48 \%$ of the 1168 total items, was the most collected plastic waste in our study. Fragments, i.e., plastics coming from the fragmentation and degradation of larger plastic items were the second common type of litter. The fragmentation of larger items is mainly driven by photo-oxidative, thermal- and biodegradation [26,38], but rates and mechanisms may vary among polymer types; $\mathrm{PE}$, for example, is more readily fragmented by weathering events, while PP is more subject to mechanical degradation. Additionally, integer objects, mostly bottle cups and straws, were quite frequently found littered in the beach and were identified as iPP and HDPE.

The polymer types and the different shapes of items suggest a variety of sources. Most of them derived from floating plastics drifting with the sea currents; some of the integer objects (like bottle cups or straws) may even have been dropped off by visitors on the beach. The presence of both integer and fragmented plastic items is not surprising since the Adriatic basin records the highest amount of floating macro-litter and the highest percentage of plastic material compared to other basins [51]. In addition, the dominance of the plastic pellets and/or plastic fragments was recorded in other studies performed on the beaches of the Adriatic coastline and Portuguese coasts [52]. Munari et al. (2017) [52] analysing microplastics in five beaches along the north-western Adriatic coast found more fragments than plastic pellets. On the contrary, Antunes et al. (2018) studying microplastics in Portuguese coasts found pellets dominant with foams being also an important part of the sampled materials. However, plastic litter typology varies depending on the type of beach and the surrounding activities.

The largest quantitates of beach plastic litter accumulated in the supra-tidal zone (medium beach) and in inland (at the base of the dune) compared to the quantities in the intertidal zone. A similar result was found by Šilc et al. (2018) [53] and Poeta et al. (2014) [54] analysing the relationship between the presence of litter and coastal dune habitats along the sea-inland gradient in the southern Adriatic coast. They highlighted the presence of an increase of litter along the sea-inland gradient, and embryo and mobile dune habitats forming were a sort of "source area" from where litter can be further distributed over dune habitats 
further inland, in particular by wind action. In the Mediterranean, even during winter storms, the action of waves and tides generally does not extend beyond these habitats.

The large presence of plastics and polystyrene on the Aquatina di Frigole beach evidences the need for further research efforts. Surely, the presence of large amounts of plastic litter has a negative impact on the environment and causes the degradation and ecological integrity loss of natural habitats protected by NATURA 2000. More research is necessary to understand the sink and sources of this ubiquitous and priority contaminant in the marine environment and biota and the kind of polymer. Mitigation plans for plastic pollution should be a strategic priority.

\section{Conclusions}

In this study, the usefulness and accuracy of using DSC to identify commercial polymers in plastic waste found on beach has been demonstrated. This instrument has the advantage of supplying reliable results in short times; only a few milligrams of material are required to analyze the sample and identify the type of plastic with this technique. Once the types of plastic composing waste have been identified, the most appropriate technique to recycle plastic waste should be encouraged because it is the only environmentally sound alternative to landfill or incineration. Recycling should also become a more feasible option, as society shifts towards a more recycling-oriented structure.

Author Contributions: The authors contributed equally to the research and manuscript preparation. All authors have read and agreed to the published version of the manuscript.

Funding: This research was supported by the $e x-60 \%$ fund from the Italian Ministry of University and Research (MIUR), by Funding of Basic Research Activities (FFABR) from (MIUR) awarded to M. Pinna, by the ImPrEco project (Interreg ADRION Programme 2014-2020) awarded to M. Pinna and by the project Dipartimenti di Eccellenza funded by MIUR to DiSTeBA.

Institutional Review Board Statement: Not applicable.

Informed Consent Statement: Informed consent was obtained from all subjects involved in the study.

Data Availability Statement: Data can be acquired from the authors.

Acknowledgments: The authors are grateful to the anonymous reviewers for their useful comments and suggestions.

Conflicts of Interest: The authors declare that they have no known competing financial interests or personal relationships that could have appeared to influence the work reported in this paper.

\section{References}

1. Plastics Europe. Plastics the Facts 2019: An analysis of European Plastics Production, Demand and Waste Data; Plasticseurope.org: Brussels, Belgium, 2019.

2. Wang, W.; Gao, H.; Jin, S.; Li, R.; Na, G. The ecotoxicological effects of microplastics on aquatic food web, from primary producer to human: A review. Ecotox. Environ. Saf. 2019, 173, 110-117. [CrossRef]

3. Teuten, E.L.; Saquing, J.M.; Knappe, D.R.U.; Barlaz, M.A.; Jonsson, S.; Björn, A.; Rowland, S.J.; Thompson, R.C.; Galloway, T.S.; Yamashita, R.; et al. Transport and release of chemicals from plastics to the environment and to wildlife. Philos. Trans. R. Soc. B Biol. Sci. 2009, 364, 2027-2045. [CrossRef]

4. Oehlmann, J.; Schulte-Oehlmann, U.; Kloas, W.; Jagnytsch, O.; Lutz, I.; Kusk, K.O.; Wollenberger, L.; Santos, E.M.; Paull, G.C.; Van Look, K.J.W.; et al. A critical analysis of the biological impacts of plasticizers on wildlife. Philos. Trans. R. Soc. B Biol. Sci. 2009, 364, 2047-2062. [CrossRef] [PubMed]

5. UNEP. Marine Litter: An Analytical Overview; UNEP Regional Seas Programme: Nairobi, Kenya, 2005; p. 58.

6. Rochman, C.M.; Browne, M.A.; Halpern, B.S.; Hentschel, B.T.; Hoh, E.; Karapanagioti, H.K.; Rios-Mendoza, L.M.; Takada, H.; Teh, S.; Thompson, R.C. Policy: Classify plastic waste as hazardous. Nature 2013, 494, 169-171. [CrossRef] [PubMed]

7. Galgani, F.; Hanke, G.; Maes, T. Global distribution, composition and abundance of marine litter. In Marine Anthropogenic Litter; Bergman, M., Gutow, L., Klages, M., Eds.; Springer Open: Berlin, Germany, 2015; pp. 29-57. ISBN 978-3-319-16510-3.

8. Gall, S.C.; Thompson, R.C. The impact of debris on marine life. Mar. Pollut. Bull. 2015, 92, 170-179. [CrossRef] [PubMed]

9. Rochman, C.M.; Browne, M.A.; Underwood, A.J.; Van Franeker, J.A.; Thompson, R.C.; Amaral-Zettler, L.A. The ecological impacts of marine debris: Unraveling the demonstrated evidence from what is perceived. Ecology 2016, 97, 302-312. [CrossRef] [PubMed] 
10. Foekema, E.M.; De Gruijter, C.; Mergia, M.T.; Van Franeker, J.A.; Murk, A.J.; Koelmans, A.A. Plastic in North Sea fish. Environ. Sci. Technol. 2013, 47, 8818-8824. [CrossRef] [PubMed]

11. Fossi, M.C.; Panti, C.; Baini, M.; Lavers, J.L. A review of plastic-associated pressures: Cetaceans of the Mediterranean Sea and eastern Australian shearwaters as case studies. Front. Mar. Sci. 2018, 5, 173. [CrossRef]

12. Giangrande, A.; Gambino, I.; Tundo, M.; Del Pasqua, M.; Licciano, M.; Fanini, L.; Pinna, M. Reproductive biology of Ophelia barquii (Annelida, Opheliidae) along the Salento Peninsula (Mediterranean Sea, South Italy). Mar. Biodivers. 2020, 50, 1-12. [CrossRef]

13. Godoy, V.; Martín-Lara, M.A.; Calero, M.; Blázquez, G. The relevance of interaction of chemicals/pollutants and microplastic samples as route for transporting contaminants. Process Saf. Environ. Prot. 2020, 138, 312-323. [CrossRef]

14. Jayasiri, H.B.; Purushothaman, C.S.; Vennila, A. Quantitative analysis of plastic debris on recreational beaches in Mumbai, India. Mar. Pollut. Bull. 2013, 77, 107-112. [CrossRef] [PubMed]

15. Godoy, V.; Prata, J.C.; Blázquez, G.; Almendros, A.I.; Duarte, A.C.; Rocha-Santos, T.; Calero, M.; Martín-Lara, M.Á. Effects of distance to the sea and geomorphological characteristics on the quantity and distribution of microplastics in beach sediments of Granada (Spain). Sci. Total Environ. 2020, 746, 142023. [CrossRef]

16. Pedrotti, M.L.; Petit, S.; Elineau, A.; Bruzaud, S.; Crebassa, J.C.; Dumontet, B.; Martí, E.; Gorsky, G.; Cózar, A. Changes in the Floating Plastic Pollution of the Mediterranean Sea in Relation to the Distance to Land. PLoS ONE 2016, 11, e0161581. [CrossRef] [PubMed]

17. Shabakaa, S.H.; Ghobashyb, M.; Mareya, R.S. Identification of marine microplastics in Eastern Harbor, Mediterranean Coast of Egypt, using differential scanning calorimetry. Mar. Pollut. Bull. 2019, 142, 494-503. [CrossRef] [PubMed]

18. Edo, C.; Tamayo-Belda, M.; Martínez-Campos, S.; Martín-Betancor, K.; González-Pleiter, M.; Pulido-Reyes, G.; García-Ruiz, C.; Zapata, F.; Leganés, F.; Fernández-Piñasb, F.; et al. Occurrence and identification of microplastics along a beach in the Biosphere Reserve of Lanzarote. Mar. Pollut. Bull. 2019, 143, 220-227. [CrossRef]

19. Vianello, A.; Boldrin, A.; Guerriero, P.; Moschino, V.; Rella, R.; Sturaro, A.; Da Ros, L. Microplastic particles in sediments of lagoon of Venice, Italy: First observations on occurrence, spatial patterns and identification. Estuar. Coast. Shelf Sci. 2013, $130,54-61$. [CrossRef]

20. Mistri, M.; Scoponi, M.; Granata, T.; Moruzzi, L.; Massara, F.; Munari, C. Types, occurrence and distribution of microplastics in sediments from the northern Tyrrhenian Sea. Mar. Pollut. Bull. 2020, 153, 111016. [CrossRef]

21. Zeri, C.; Adamopouloua, A.; Bojanić Varezić, D.; Fortibuonic, T.; Kovač Viršeke, M.; Kržanf, A.; Mandicg, M.; Mazziotti, C.; Palatinuse, A.; Peterline, M.; et al. Floating plastics in Adriatic waters (Mediterranean Sea): From the macro- to the micro-scale. Mar. Pollut. Bull. 2018, 136, 341-350. [CrossRef]

22. Käppler, A.; Fischer, D.; Oberbeckmann, S.; Schernewski, G.; Labrenz, M.; Eichhorn, K.; Voit, B. Analysis of environmental microplastics by vibrational micro- spectroscopy: FTIR, Raman or both? Anal. Bioanal. Chem. 2016, 408, 8377-8391. [CrossRef]

23. Majewsky, M.; Bitter, H.; Eiche, E.; Horn, H. Determination of microplastic polyethylene (PE) and polypropylene (PP) in environmental samples using thermal analysis (TGA-DSC). Sci. Total Environ. 2016, 568, 507-511. [CrossRef] [PubMed]

24. Rocha-Santos, T.; Duarte, A.C. A critical overview of the analytical approaches to the occurrence, the fate and the behaviour of microplastics in the environment. Trends Anal. Chem. 2015, 65, 47-53. [CrossRef]

25. Orfanidis, S.; Papathanasiou, V.; Sabetta, L.; Pinna, M.; Gigi, V.; Gounaris, S.; Tsiagga, E.; Nakou, K.; Theodosiou, T.H. Benthic macrophyte communities as bioindicators of transitional and coastal waters: Relevant approaches and tools. Transit. Waters Bull. 2007, 1, 45-49.

26. Fonnesu, A.; Pinna, M.; Basset, A. Spatial and temporal variations of detritus breakdown rates in the river Flumendosa basin (Sardinia, Italy). Int. Rev. Hydrobiol. 2004, 89, 443-452. [CrossRef]

27. Pinna, M.; Janzen, S.; Franco, A.; Specchia, V.; Marini, G. Role of habitats and sampling techniques on macroinvertebrate descriptors and ecological indicators: An experiment in a protected Mediterranean lagoon. Ecol. Indic. 2017, 83, 495-503. [CrossRef]

28. Marrocco, V.; Zangaro, F.; Sicuro, A.; Pinna, M. A scaling down mapping of Pinna nobilis (Linnaeus, 1758) through the combination of scientific literature, NATURA 2000, grey literature and citizen science data. Nat. Conserv. 2019, 33, 21-31. [CrossRef]

29. Marrocco, V.; Sicuro, A.; Zangaro, F.; Pinna, M. First record of the protected species Pinna nobilis (Linnaeus, 1758) in the Aquatina Lagoon (NATURA 2000 site IT9150003, South-East Italian coastline). Nat. Conserv. 2018, 28, 51-59. [CrossRef]

30. Specchia, V.; Tzafesta, E.; Marini, G.; Scarcella, S.; D'Attis, S.; Pinna, M. Gap analysis for DNA barcode reference libraries for aquatic macroinvertebrate species in the Apulia Region (Southeast of Italy). J. Mar. Sci. Eng. 2020, 8, 538. [CrossRef]

31. Chialanza, M.R.; Sierra, I.; Pérez Parada, A.; Fornaro, L. Identification and quantitation of semi-crystalline microplastics using image analysis and differential scanning calorimetry. Environ. Sci. Pollut. Res. 2018, 25, 16767-16775. [CrossRef] [PubMed]

32. Menczel, J.D.; Prime, R.B. Thermal Analysis of Polymers: Fundamentals and Applications; John Wiley \& Sons, Inc.: Hoboken, NJ, USA, 2009.

33. Billmeyer, F.W., Jr. Textbook of Polymer Science, 2nd ed.; John Wiley \& Sons Inc.: New York, NY, USA, 1971.

34. Gedde, U.W. Polymer Physics, Kluwer, 1st ed.; Chapman \& Hall: London, UK, 1995.

35. Gómez, E.F.; Michel, F.C., Jr. Biodegradability of conventional and bio-based plastics and natural fiber composites during composting, anaerobic digestion and long-term soil incubation. Polym. Degrad. Stabil. 2013, 98, 2583-2591. [CrossRef]

36. Vona, I.A.; Costanza, J.R.; Cantor, H.A.; Roberts, W.J. Manufacture of Plastics; Wiley: New York, NY, USA, $1965 ;$ Volume 1. 
37. Nowak, B.; Pajak, J.; Drozd-Bratkowicz, M.; Rymarz, G. Microorganisms participating in the biodegradation of modified polyethylene films in different soils under laboratory conditions. Int. Biodeterior. Biodegr. 2011, 65, 757-767. [CrossRef]

38. Andrady, A.L. Microplastics in the marine environment. Mar. Pollut. Bull. 2011, 62, 1596-1605. [CrossRef]

39. Browne, M.A.; Galloway, T.S.; Thomson, R.C. Microplastic An emerging contaminant of potential concern? Integr. Environ. Assess. Manag. 2007, 3, 559-566. [CrossRef] [PubMed]

40. Wang, J.; Tan, Z.; Peng, J.; Qiu, Q.; Li, M. The behaviors of microplastics in the marine environment. Mar. Environ. Res. 2016, 113, 7-17. [CrossRef] [PubMed]

41. Carbery, M.; O'Connor, W.; Thavamani, P. Trophic transfer of microplastics and mixed contaminants in the marine food web and implications for human health. Environ. Int. 2018, 115, 400-409. [CrossRef]

42. Mouat, J.; Lozano, R.L.; Bateson, H. Economic Impacts of Marine Litter; KIMO International: Grandfield, UK, 2010 ; p. 105.

43. Thompson, R.C.; Moore, C.J.; vom Saal, F.S.; Swan, S.H. Plastics, the environment and human health: Current consensus and future trends. Philos. Trans. R. Soc. Lond. B Biol. Sci. 2019, 364, 2153-2166. [CrossRef]

44. Engler, R.E. The complex interaction between marine debris and toxic chemicals in the ocean. Environ. Sci. Technol. 2012, 46, 12302-12315. [CrossRef] [PubMed]

45. Pham, C.K.; Ramirez-Llodra, E.; Alt, C.H.; Amaro, T.; Bergmann, M.; Canals, M.; Company, J.B.; Davies, J.; Duineveld, G.; Galgani, F.; et al. Marine litter distribution and density in European seas, from the shelves to deep basins. PLoS ONE 2014, 9, e95839. [CrossRef]

46. Ponti, M.; Vadrucci, M.R.; Orfanidis, S.; Pinna, M. Biotic indices for ecological status of transitional water ecosystems. Transit. Waters Bull. 2009, 3, 32-90.

47. Zangaro, F.; Schifano, V.; Specchia, V.; Tzafesta, E.; Pinna, M. A new extralimital sighting of Monachus monachus (Hermann, 1779) in the Aquatina di Frigole NATURA 2000 site (IT9150003) beach (Salento peninsula, Apulia Region, Italy) after two decades: Strategies for conservation are needed. Biodivers. Data J. 2020, 8, e53950. [CrossRef]

48. Brignac, K.C.; Jung, M.R.; King, C.; Royer, S.J.; Blickley, L.; Lamson, M.R.; Potemra, J.T.; Lynch, J.M. Marine debris polymers on main Hawaiian Island beaches, sea surface and seafloor. Environ. Sci. Technol. 2019, 53, 12218-12226. [CrossRef]

49. Massos, A.; Turner, A. Cadmium, lead and bromine in beached microplastics. Environ. Pollut. 2017, 227, 139-145. [CrossRef]

50. Schwarz, A.E.; Ligthart, T.N.; Boukris, E.; van Harmelen, T. Sources, transport, and accumulation of different types of plastic litter in aquatic environments: A review study. Mar. Pollut. Bull. 2019, 143, 92-100. [CrossRef] [PubMed]

51. Arcangeli, A.; Campana, I.; Angeletti, D.; Atzori, F.; Azzolin, M.; Carosso, L.; Di Miccoli, V.; Giacoletti, A.; Gregorietti, M.; Luperini, C.; et al. Amount, composition, and spatial distribution of floating macro litter along fixed trans-border transects in the Mediterranean basin. Mar. Pollut. Bull. 2018, 129, 545-554. [CrossRef]

52. Munari, C.; Corbau, C.; Simeoni, U.; Mistri, M. Marine litter on Mediterranean shores: Analysis of composition, spatial distribution and sources in north-western Adriatic beaches. Waste Manag. 2016, 49, 483-490. [CrossRef] [PubMed]

53. Šilc, U.; Küzmič, F.; Caković, D.; Stešević, D. Beach litter along various sand dune habitats in the southern Adriatic (E Mediterranean). Mar. Pollut. Bull. 2018, 128, 353-360. [CrossRef] [PubMed]

54. Poeta, G.; Battisti, C.; Acosta, A.T.R. Marine litter in Mediterranean sandy littorals: Spatial distribution patterns along central Italy coastal dunes. Mar. Pollut. Bull. 2014, 89, 168-173. [CrossRef] 